\title{
The Notion of Delegated Legislation in India- A Critical Analysis
}

\section{Ashish Srivastava*}

3rd Year Student, National University of Study and Research in Law, AT- Nagri, P.O Bukru, Kanke-Pithoria Road, Kanke, Ranchi, Jharkhand 834006, India

\author{
DOI: $10.36348 /$ sijlcj.2019.v02i11.002 \\ | Received: 29.10.2019 | Accepted: 05.11.2019 | Published: 12.11.2019 \\ *Corresponding author: Ashish Srivastava
}

\section{Abstract}

Delegated legislation is one of the most debated practice in the domain of legal field. As it has various implications, experts all around the country have taken different stands on the issue. Even though it has gained the acceptability in our system, there have been contrary views about delegated legislation. For instance, one of the settled maxims in Constitutional law and Administrative law is "DELEGATA POTESTAS NON POTEST DELEGARE" which means one to whom power is delegated cannot himself further delegate that power. Where the sovereign power of the State has been vested to an authority, it must remain in the vested authority; and by it alone the laws should be made .The power to whose judgment, wisdom, and patriotism this high prerogative has been entrusted cannot relieve itself by dodging away with the responsibility of performing its functions and by choosing other agencies upon which the power could be devolved. The reason is found in the very existence of its own powers. This high prerogative has been entrusted to its own wisdom, judgment, and patriotism, and not to those of other persons, and it will act ultra vires if it undertakes to delegate the trust, instead of executing it. While such scenarios do raise the questions about the legality of delegating the power by higher legislative bodies to the lower ones, the fact remains that this has been an accepted norm and a general practice followed in all modern democratic countries. Hence it is imperative to make a critical analysis of the same so as to understand the associated norms and intricacies of Delegated Legislation.

Keywords: Delegated legislation, DELEGATA POTESTAS NON POTEST DELEGARE, wisdom, patriotism.

Copyright @ 2019: This is an open-access article distributed under the terms of the Creative Commons Attribution license which permits unrestricted use, distribution, and reproduction in any medium for non-commercial use (NonCommercial, or CC-BY-NC) provided the original author and source are credited.

\section{INTRODUCTION}

The current trend, in almost every democratic country is, to promote the idea of delegation I.E to transfer some functions of the legislature to the executive and eventually make the executive promulgate the functions of the legislature $\left[{ }^{1}\right]$. This is carried out to ensure that the legislature is not overburdened in any way and some set of functions can be decentralized. According to Salmond, delegation refers to the idea that some powers are exercised by authorities other than sovereign power and these powers can only be exercised upon approval from other superior authority. In essence, no delegation of powers can happen without approval from a superior authority.

Delegated legislation (also referred to as secondary legislation or subordinate legislation or subsidiary legislation) is law made by an executive

${ }^{1}$ MP JAIN AND SN JAIN, PRINCIPLES OF ADMINISTRATIVE LAW, 42 (Justice GP Singh and Justice Alok Aradhe, 6th edn., 2013). authority under powers given to them by primary legislation in order to implement and administer the requirements of that primary legislation. It is law made by a body other than the legislature but with the legislature's authority. Without the legislature's authority it cannot be carried out. Often, a legislature passes statutes that set out broad guidelines and principles, and delegates authority to an executive branch and provide procedures for implementing the substantive provisions of the statute $\left[{ }^{2}\right]$.

So, in lay man terms Delegated Legislation means that legislation which proceeds from any authority other than the sovereign power and therefore is dependant for its continued existence or validity on some superior or omnipotent authority. Legislation is further sub divided into two category 1) Fundamental / Essential legal function 2) Ancillary / Incidental. The legislation created by delegated legislation must be made in accordance with the purposes laid down in the

${ }^{2}$ Cooley's Constitutional Limitations, Volume I at page 224 
Act. It is to be noted that delegation of essential legal function can never be done and doing this would amount to Excessive delegation. Therefore, two tests are to be always kept in mind while deciding whether the concerned delegation is an excessive delegation or not:

- Whether there was a legislative policy laid or not.

- Whether essential legal function has been delegated or not

\section{ADVANTAGES OF DELEGATED LEGISLATION}

One of the advantages of delegated legislation is it permits the Government to amend a law without having to wait for a new Act to be passed by the parliament. Further, it is to be noted that delegatedlegislation can be used only to make technical changes to the law, such as altering sanctions under a given statute. Any essential legal function cannot be carried out through delegated legislation. Nor a delegated body can lay down a legislative policy. For example, a Local Authority have power given to them under certain statutes to allow them to make delegated legislation and to make law which suits their area. Delegated legislation provides a very important role in the making of law as there is more delegated legislation enacted each year than there are Acts of Parliament. In addition, delegated legislation has the same legal standing as the Act of Parliament from which it was created.

Another important reason why delegated legislation is important is it avoids overloading the limited Parliamentary timetable as delegated legislation can be amended and/or made without having to pass an Act through Parliament, which can be time consuming. Changes can therefore be made to the law without the need to have a new Act of Parliament and it further avoids Parliament having to spend a lot of their time on technical matters, such as the clarification of a specific part of the legislation.

It is to be noted that it is humanly impossible for the parliament to look upon all the matters. As there would be some tasks which will require some specific kind of expertise. So, in such situation delegated legislation would be very beneficial. Delegated legislation allows law to be made by those who have the relevant expert knowledge. By way of illustration, a local authority can make law in accordance with what their locality needs as opposed to having one law across the board which may not suit their particular area. A particular Local Authority is in a better position to decide what is best for their locality and can make a law to suit their local needs.

Fourthly, delegated legislation can deal with an emergency situation as it arises without having to wait for an Act to be passed through Parliament to resolve the particular situation.
Also delegated legislation is more flexible in nature in comparison to the legislative body I.E parliament. Delegated Legislation can be used to battle a situation that Parliament had not anticipated at the time it enacted the piece of legislation, which makes it very useful to law-making. Delegated legislation is therefore able to meet the changing needs of society and also situations which Parliament had not anticipated when they enacted the Act of Parliament $\left[{ }^{3}\right]$.

Another strong advantage delegated legislation has is Experiment: The practise of delegated legislation enables the Executive to experiment. For example, in traffic matters of the road an experiment method can be conducted and in the wake of its application necessary changes can be made in the provisions. The advantages of such a course is that it allows the delegated authority to consult the interest of people at the ground level that what type of law is affecting them and then he makes an experiment by altering the provisions.

A portion of law-making power of the legislative is conferred or bestowed upon a subordinate authority. Rules \& regulations which are to be framed by the latter constitutes an integral portion of the statute itself.

\section{CLASSIFICATION OF DELEGATED LEGISLATION} DISTINCTION BASED ON AUTHORITY: On the basis of authority delegated legislation is further subdivided into two category:

- Ordinary Delegated Legislation: It is that legislation in which a parent body transfers some ancillary functions to a delegated body. It is to be noted that the parent body isn't allowed to delegate the essential legal functions like amendment of any statute, repeal of any statute etc as it would amount to excessive delegation.

- Sub- delegation: It is to ne noted that prima facie sub delegation is not allowed, but if in a parent act it is given that a delegated body can further sub-delegate, then it is allowed. According to one of the legal maxims "delegatus non potest delegare" a delegate cannot further sub-delegate the powers. But this maxim is applied flexibly. So, it does not bar the sub -delegation. If a parent body has a substantive control over the sub delegated body or if there is any necessary implications present, the sub- delegation is very much valid. So, if the authority further delegates its lawmaking power to some other authority and it retains a general control of substantial nature over it, there is no delegation as to attract the doctrine of "delegatus non potest delegare". Therefore, if the administrative authority

\footnotetext{
3 Jain, M.P. \& Jain, S.N.; (2007) Principles of
} Administrative Law, 6th Ed., Vol. II, Wadhwa Nagpur. 
which has been delegated the power to impose and collect tax, delegates only the collection part to some other agency, it will not be a case of sub- delegation $\left[{ }^{4}\right]$.

DISCRETION BASED CLASSIFICATION: On the basis of "discretion", administrative rule -making may be classified into:-

- Subordinate legislation: In subordinate legislation, the process consists of the discretionary elaboration of rules and regulations $\left[{ }^{5}\right]$.

- Conditional/Contingent legislation: It may be defined as a statute that provides control but specifies that they are to go into effect only when a given administrative authority finds the existence of conditions defined in the statute itself. Legislation of sub-ordinate becomes active only after the fulfilment of the conditions. So, it is mainly confined to activation of laws.

The distinction between the two is of "discretion". Contingent or conditional legislation is fact - finding and sub-ordinate legislation is discretionary. Also, in conditional legislation the gun and the gun powder is provided by legislature and the administrative authority is only required to pull the trigger, but in sub-ordinate legislation the administrative authority is to manufacture the gunpowder also.

\section{LEGISLATION DEVELOPMENT POST INDEPENDENCE}

Essentially, delegation was considered as an English legacy. Whether there could be any continuance of the same, was taken up in the case of In Re Delhi laws case $\left[{ }^{6}\right]$, as the seven- judge bench was asked by the President of India, under the powers allotted to him under Article 143 of the constitution, if delegated powers could be considered valid in any form $\left[{ }^{7}\right]$.

The Supreme Court, after a lengthy deliberation upon the issues, came down to the following set of conclusions-

1-The Parliament could not be allowed to absolve itself of its responsibility entirely by creating a parallel authority. 2- The Indian parliament was not an

\footnotetext{
${ }^{4}$ M. Chandru v. Chennai Metropolitan Development Authority, (2009) 4 SCC 72.

${ }^{5}$ CK Takwani, Lectures on Administrative Law (5th, Eastern Book Company, Lucknow 2012) 1.

${ }^{6} 1951$ AIR 332.

7 manupatra.com, In Re Delhi Laws Case: Landmark in Delegated Legislation in India, Chavi Agarwal, available at http://www.manupatra.com/roundup/333/Articles/In\%2 0re\%20Delhi\%20Laws\%20Act\%20Case.pdf.
}

agent but an authority in itself. Thus, the concept of "delegatus non potest delegare", which means that a power that has been delegated cannot be sub-delegated any further, was propounded. 3- The Court suggested that the parliament could only delegate its ancillary functions. 4- The court also concluded that essential functions- ones which involved laying down of policies and their implementation as binding rule of law could not be delegated. However, it was also seen that the degree of delegation of powers was also given a serious look in. While, one school of thought was that the supreme authority should be allowed to withdraw the powers so delegated, which will also make sure that the authority hasn't absolved itself of its rightful powers. The other school of thought opined that the supreme authority could set up "standards" for execution of its policies that the delegate must compulsorily adhere to while taking decisions. It is to be noted, even though this case being the landmark case, its ratio in the judgment was altered by later decisions. As seen in $D S$ Garewal v State of Punjab $\left[{ }^{8}\right]$, the idea of powers of delegation being an essential element of the legislature's powers and the legislature having inherent powers to delegate its functions was deemed appropriate.

In another famous case of Lachmi Narain $v$ Union of India $\left[{ }^{9}\right]$ the idea of powers of delegation was discussed. The facts of the case were that the Central Government by the virtue of section 2 of the Part State (Laws) Act, 1950 extended the Bengal Finances (Sales Tax) Act, 1941 to the Part State of Delhi with certain modification in Section 6 through a notification. By various notifications, the granted sales tax on various commodities was exempted but subsequently, the exemption was withdrawn by another notification. Dealers who are indulging in those commodities, challenges the validity of that withdrawal. Court held in this case that the notification issued by the Central Government is beyond its power and in consequence of any type of notification issued by the Central Government is invalid and ineffective.

In case of Raj Narain Singh v Chairman Patna Administration committee $\left[{ }^{10}\right]$ section $3(1)(\mathrm{f})$ of Bihar \& Orissa Act, empowered the local administration to extend the provisions of any sections of the act ( Bengal Municipality Act, 1884) to Patna subject to such modification, as it might think fit. The government picked up section 104 and after making certain modifications applied it to the town of Patna. One of the essential features of the Act was that no municipality competent to tax could be thrust upon a locality without giving its inhabitants a chance of being heard and of being given as opportunity to object. The sections which provided for an opportunity to object were

\footnotetext{
81959 SCR Supl. (1) 792.

91976 SCR (2) 785.

${ }^{10}$ AIR 1954 SC 569.
} 
excluded from the notification. It was held as amounting to tamper with the policy of the Act.

\section{RESTRICTIONS ON DELEGATED LEGISLATION JUDICIAL CONTROL}

One of the ways by which a check could be put on Delegated Legislation is Judicial Control. Judicial control will make sure that if any delegated legislation is arbitrary in nature, it should be declared as unconstitutional. So, on grounds of arbitrariness the delegated legislation may be declared as unconstitutional. Also, the judiciary will look into the fact that whether statutory power has been properly exercised or not. The scope of permissible delegation is quite broad. The delegated legislation should not infringe the provisions of the constitution and if it does it would amount to ultra vires the constitution. If the Act of the Legislature under which power is delegated, is ultra vires, the power of the legislature in the delegation can never be good. Besides the constitutional attack, the delegated legislation may also be challenged as being ultra vires the powers of the administrative body framing the rules and regulations. It could be so if that run counter to the provisions of the act or that they have been made in excess of the authority delegated by the Legislature.

\section{LEGISLATIVE CONTROL}

Another way by which some restrictions could be put on delegated legislation is Legislative Control. Legislation is an inherent and inalienable right of Parliament and it has to be seen that this power is not transgressed under the guise of what is called subordinate legislation $\left[{ }^{11}\right]$. Legislative control could restrict the normal delegation in two manners. 1) POSITIVE: it is the case where the limits of delegation are clearly defined in the enabling Act. 2) NEGATIVE: Omission of certain powers to stop the delegated body to do certain thing.

\section{CRITICISMS OF DELEGATED LEGISLATION}

- Many a times what happens that the legislature passes only the skeleton laws and general policies, leaving the rest upon the executive body. So, there is a bifurcation of wide discretion and power to the executive body which might be misused to trump upon the life and liberty of people.

- Delegated legislation involves lack of publicity surrounding it. It is to be noted that when law is made by statutory instrument the public are not normally notified of it whereas the scenario is just opposite in the case of parliament passing the Acts which are widely publicized. One of the possible reasons for the lack of publicity surrounding delegated legislation is because of the volume of delegated legislation made and this result in the public not being informed of the changes to law. Also, another concern regarding delegated legislation is that laws made via delegated legislation has increased manifolds.

- It lacks democracy as too much delegated legislation is made by unelected people.

- Even though judicial control could be exercised to check the legality of delegated legislation, it becomes very technical and complex when it is to be applied in reality.

- There is no central system available to look into inconsistencies in delegated legislations and suggest remedies accordingly.

\section{CONCLUSION}

Thus, summing up, even though delegated legislation helps in lessening the burden of the parliament, at times it functions in such manner that may lead to injustice and arbitrariness. Also, there is no hiding to the fact that whenever any subordinate legislation is scrutinized, a lot of complexities arises thereby making the process inefficacious. Delegation helps in ensuring better administration. Justice $\mathrm{P}$ B Mukherjee has stated "Delegated legislation is an expression which covers a multitude of confusion. It is an excuse for the legislators, a shield for the administrators and a provocation to the constitutional jurists. It is praised as a necessity and felt as inevitable in our world where social economic technological psychological and administrative speed outstrips the spacious and placid traditional legislative ideals and processes. It is criticized as an abdication of power by legislators and an escape from the duty imposed on them by voters of democracy" [12]. But if the same is not handled properly, will lead to undesired results. As it could be seen in many cases that the legislative body only make the skeleton laws and the other important things are delegated to a executive body which may make the process arbitrary. As by doing this it would allow the delegated body to enjoy wide powers and discretions. Such bifurcation of powers is highly problematic. If we really want to make the practice of delegated legislation a living continuity, it is imperative for us to make a separate central system which would directly look after the affairs of delegated legislation. To come up with a uniform guidelines which would govern the working of the delegated body.

\footnotetext{
${ }^{11}$ prsindia.org, Parliamentary Scrutiny of Executive Rule Making Background Note for the Conference on Effective Legislatures, November 15,2012, available at http://www.prsindia.org/administrator/uploads/general/ 1370586704_Parliamentary\%20Scrutiny\%20of\%20Exe xecutive\%20Rule\%20Making.pd
}

12 JIL 1 July 1959. 